Table 2 Neuronal number in the $L_{6}$ DRG after lesioning of the central and/or peripheral processes in NGF-immunized guinea pigs

\begin{tabular}{ccccc}
\hline & \multicolumn{3}{c}{ Lesion } & Cell no. \\
Group & Central & Peripheral & in L6 DRG & $\%$ Control \\
A & - & - & $18,113 \pm 815(7)$ & $100^{*}$ \\
B & + & - & $13,589 \pm 996(3)$ & 75 \\
C & - & + & $14,695 \pm 726(3)$ & 81 \\
D & + & + & $10,641 \pm 711(4)$ & $59^{*}$ \\
\hline
\end{tabular}

* Statistically different from all other groups (maximum $P<0.054$ ).

NGF may be taken up by central terminals in the spinal cord and retrogradely transported by the central process to the DRG. Antibodies to NGF presumably would not cross the blood-brain barrier and would not prevent access of the DRG neurone to central nervous system (CNS)-derived NGF (or other trophic factor).

The data in Table 2 show the effects on sensory neurones of lesioning either the central or peripheral process or both in a group of animals chronically deprived of NGF. The peripheral lesion alone results in $\sim 20 \%$ loss of DRG neurones ${ }^{8}$. However, in the NGF-deprived animal, cutting only the central process resulted in a $25 \%$ loss. In anti-NGF-producing animals subjected to a peripheral crush and a central lesion, a further neuronal loss of $27 \%(14,695-10,641)$ is observed. Thus, when the trophic support of peripherally derived NGF is removed, at least some populations of sensory neurones become dependent on centrally derived trophic support for survival. Conversely, when deprived of trophic support through the central process, at least a proportion of sensory neurones requires peripheral NGF for survival.

These results suggest that survival of sensory neurones in the adult animal depends on trophic support from both the central and peripheral targets. As peripheral NGF deprivation produces atrophy but not cell death of DRG neurones, whereas crushing the nerve does produce $(\sim 25 \%)$ cell death, we suggest that NGF is but one of possibly several peripherally provided molecules that trophically support DRG neurones. As NGF deprivation plus central lesion produces an amount of cell death comparable with that caused by peripheral crush lesion, the total trophic support provided by the central process is equivalent to the non-NGF component of peripheral trophic

Received 24 September 1984; accepted 12 February 1985

1. Lieberman, A. R. Int. Rev. Neurobiol. 14, 49-124 (1971)

2. Hamburger, V. \& Oppenheim, R. W. Neurosci. Comment. 1, 39-55 (1982).

3. Gorin, P. D. \& Johnson, E. M. Proc. natn. Acad. Sci. U.S.A. 76, 5382-5386 (1979)

4. Johnson, E. M., Gorin, P. D., Brandeis, L. D. \& Pearson, J. Science 210, 916-918 (1980)

5. Aloe, L., Cozzani, C., Calissano, P. \& Levi-Montalcini, R. Nature 291, 413-415 (1981).

6. Pearson, J., Johnson, E. M. \& Brandeis, L. Devl Biol. 96, 32-36 (1983).

7. Schwartz J. P. Pearson, J. \& Johnson, E. M. Brain Res 244, 378-381 (1982).

8. Rich, K. M., Yip, H. K., Osborne, P. A., Schmidt, R. E. \& Johnson, E. M. J. comp. Neurol 230, 110-118 (1984) support. Thus, the loss of any one of these three trophic components (peripheral NGF, peripheral non-NGF, centrally derived factor) produces atrophy but not death. Removal of any two of these components results in loss of $\sim 20 \%$ of cells. Loss of all three components would therefore be expected to result in the death of even more cells (Table 2). The data in Table 1 suggest that central process lesion may increase the severity of a peripheral crush in control animals, but the decrease in neuronal number is not statistically significant. Thus, we propose that the trophic support of a DRG neurone in the adult animal is represented by the sum of the trophic effects of NGF and other unknown factors derived from the periphery and a factor or factors derived from the CNS, one of which may be NGF. Based on our limited data, we cannot provide a complete explanation of this hypothesis. Interpretation is complicated by the fact that the DRG is composed of heterogeneous cell types. We do not know, for example, whether the $20 \%$ of cells that die after peripheral lesion are the same cells that die after peripheral NGF deprivation combined with a central lesion. In addition, the experiment used a peripheral crush lesion rather than a cut; thus, regeneration of the distal processes was possible and probably rather efficient ${ }^{8}$. Greater cell loss would be expected if the sciatic nerve were cut rather than crushed. Similarly, $15-20 \%$ of neurones in $\mathrm{L}_{6}$ DRG do not project down the sciatic nerve and some neurones may reach the CNS via the ventral root, rather than the dorsal root ${ }^{15}$

Irrespective of the complications in providing a precise accounting of the cell death, the fact that trophic support for sensory neurones is provided via their central processes seems to explain the apparent lack of dependency of mature sensory neurones on NGF for survival, deduced by experiments using anti-NGF. The data suggest that survival of sensory neurones is dependent on relative trophic support provided by both the central and peripheral processes, although the quantitative support by the peripheral process is overall more important in adult animals. Because in newborn rats cell losses after lesioning of the central or peripheral process are the same ${ }^{13}$, the results indicate that the relative importance of the trophic support provided by the central and peripheral processes changes as a function of age.

This work was supported by NIH grants NS18071, HL20604 and NS07129. We thank Ms Patricia Osborne and Ms Patricia Lampe for assistance and Dr Keith Rich for advice.

9. Levi-Montalcini, R. \& Angeletti, P. U. Physiol. Rev. 48, 534-569 (1968).

10. Thoenen, H. \& Barde, Y. A. Physiol. Rev. 60, 1284-1335 (1980).

11. Hinsey, J. C., Krupp, M. A. \& Lhamon, W T. J. comp. Neurol 67, 205-214 (1937).

12. Hare, W. K. \& Hinsey, J. C. J. comp. Neurol. 73, 489-502 (1940).

13. Yip, H. K. \& Johnson, E. M. Proc. natn. Acad. Sci. U.S.A. 81, 6245-6249 (1984).

14. Richardson, P. M. \& Riopelle, R. J. J. Neurosci. 4, 1683-1689 (1984)

15. Coggeshall, R. E. Neurosurgery 4, 443-448 (1979).

16. Snedecor, G. W. in Statistical Methods (Iowa University Press, 1957)

17. Konigsmark, B. E. in Contemporary Research Methods in Neuroanatomy (eds Nauta, W. H. \& Ebbesson, S. O. E.) 315-340 (Springer, New York, 1970).

\title{
Erratum
}

\section{Lower mantle heterogeneity, dynamic topography and the geoid}

\author{
B. H. Hager, R. W. Clayton, M. A. Richards, R. P. Comer \& A. M. Dziewonski
}

Nature 313, 541-545 (1985).

IN this article Table 1 was omitted. It should read:

Table 1 Correlation coefficients for degrees 2-6 for model geoids predicted using two models of lower mantle heterogeneity (Dz and CC), convolved with dynamic response functions for Earth model U10

\begin{tabular}{|c|c|c|c|c|c|c|c|c|c|c|}
\hline \multirow[b]{2}{*}{ Degree } & \multicolumn{5}{|c|}{ Model geoid CC-U10 } & \multicolumn{5}{|c|}{ Model geoid Dz-U10 } \\
\hline & 2 & 3 & 4 & 5 & 6 & 2 & 3 & 4 & 5 & 6 \\
\hline $\begin{array}{l}\text { Observed geoid } \\
\text { Residual geoid } \\
\text { Model geoid Dz-U10 }\end{array}$ & $\begin{array}{l}0.84 \\
0.95 \\
0.79\end{array}$ & $\begin{array}{l}0.76 \\
0.77 \\
0.66\end{array}$ & $\begin{array}{r}0.34 \\
-0.25 \\
0.01\end{array}$ & $\begin{array}{r}-0.17 \\
-0.35 \\
0.12\end{array}$ & $\begin{array}{r}-0.02 \\
-0.33 \\
0.31\end{array}$ & $\begin{array}{l}0.68 \\
0.82\end{array}$ & $\begin{array}{l}0.74 \\
0.79\end{array}$ & $\begin{array}{l}-0.24 \\
-0.39\end{array}$ & $\begin{array}{l}0.24 \\
0.27\end{array}$ & $\begin{array}{r}0.17 \\
-0.03\end{array}$ \\
\hline
\end{tabular}

The models are correlated against the observed geoid, a residual geoid with slab effects removed ${ }^{10}$, and each other. 